\title{
PERBANDINGAN KARAKTER MORFOMETRIK KERANG LUMPUR Anodontia edentula Linnaeus, 1758 DI PULAU TOBEA DAN PESISIR LAMBIKU, KECAMATAN NAPABALANO, KABUPATEN MUNA
}

\author{
COMPARISON OF MORPHOMETRICS CHARACTERS OF MUDCLAMS \\ Anodontia edent UIa LINNAEUS, 1758 IN TOBEA ISLAND AND THE COAST OF LAMBIKU, \\ NAPABALANO DISTRICT OFMUNA REGENCY
}

\author{
Rochmady1), Sharifuddin Bin Andy Omar², dan Lodewyck S. Tandipayuk ${ }^{2)}$ \\ 1) Sekolah Tinggi Ilmu Pertanian Wuna (STIP Wuna) Raha. \\ 绝+6285343880383凶k kampo.mokesano@gmail.com \\ 2) Fakultas Ilmu Kelautan dan Perikanan, Universitas Hasanuddin, Makassar.
}

\begin{abstract}
The objective of the research was to investigate the morphometric characters of mudclams, Anodontia edentula Linnaeus, 1758 in Tobea Island and in the coast of Lambiku, Napabalano District of Muna Regency. The research carried out in Tobea island and in the coast of Lambiku was to analyse morphometrics character of mudclams. Data were analysed to perceive the comparison of morphometrics characters of mudclams in Tobea island and in the coast of Lambiku by using t-test (student) and descriptive analysis.

The results of t-test (student) analysis showed morphometric characters of mudclams in Tobea Island and in the coast of Lambiku significantly different as indicated by the t-value is greater than t-tables at the confidence level $(\alpha=0.05)$. The morphometric characters of mudclams between the male sex in Tobea island and male in the coast of Lambiku different significantly as indicated by the t-value is greater than t-tables at the convidence level $(\alpha=0.05)$. The morphometric characters of mudclams at the confidence level at the male sex in Tobea island and female in the coast of Lambiku significantly different as indicated by the tvalue is greater than t-table. For morphometric characters mudclams in Tobea island of female and male sex significantly different in the coast of Lambiku as indicated by the t-value is greater than t-table. Morphometric characters in female of mudclams in Tobea Island and female gender were significantly different in the coast of Lambiku .

Morphometric characters of mudclams in Tobea Island tend to be smaller than in the coast of Lambiku which the mudclams there tends to be larger.
\end{abstract}

Keywords : Mudclams Anodontia edentula, morphometric, Tobea island, the coast of Lambiku.

\begin{abstract}
ABSTRAK
Penelitian dilakukan di Pulau Tobea dan Pesisir Lambiku dengan tujuan untuk menganalisis karakter morfometrik kerang lumpur. Data dianalisis untuk membandingkan karakter morfometrik kerang lumpur daerah Pulau Tobea dan Pesisir Lambiku dengan menggunakan analisis uji-t (student) dan deskriptif.

Hasil analisis uji-t (student) menunjukkan karakter morfometrik kerang lumpur di Pulau Tobea berbeda nyata dengan Pesisir Lambiku yang ditunjukkan dengan nilai thitung lebih besar dari t tabel pada taraf kepercayaan $(\alpha=0,05)$. Karakter morfometrik kerang lumpur antara jenis kelamin jantan di Pulau Tobea dan jantan di Pesisir Lambiku berbeda nyata yang ditunjukkan
\end{abstract}


dengan nilai $\mathrm{t}$ hitung lebih besar dari $\mathrm{t}$ tabel pada taraf kepercayaan $(\alpha=0,05)$. Karakter morfometrik kerang lumpur antara jenis kelamin jantan di Pulau Tobea dan jenis kelamin betina di Pesisir Lambiku berbeda nyata yang ditunjukkan dengan nilai t hitung lebih besar dari t tabel. Untuk karakter morfometrik kerang lumpur jenis kelamin betina di Pulau Tobea dan jenis kelamin jantan di Pesisir Lambiku berbeda nyata yang ditunjukkan dengan nilai t hitung yang lebih besar dari t tabel. Karakter morfometrik kerang lumpur jenis kelamin betina di Pulau Tobea dan jenis kelamin betina di Pesisir Lambiku berbeda nyata yang ditunjukkan dengan nilai t hitung lebih besar dari t tabel, masing-masing pada taraf kepercayaan $(\alpha=0,05)$.

Kerang lumpur di Pulau Tobea, memiliki karakter morfometrik yang cenderung lebih kecil dibandingkan dengan kerang lumpur di Pesisir Lambiku yang cenderung lebih besar.

Kata kunci : Kerang lumpur Anodontia edentula, morfometrik, Pulau Tobea, Pesisir Lambiku

\section{BAB I. PENDAHULUAN}

\subsection{Latar Belakang}

Pulau Tobea merupakan salah satu pulau yang berada di gugusan Kepulauan Tobea yang berada di sebelah Utara Pulau Muna. Pesisir Lambiku merupakan daerah aliran sungai Lambiku yang terletak di sebelah Timur Pulau Muna, Kecamatan Napabalano, Kabupaten Muna. Pulau Tobea dan Pesisir Lambiku adalah dua daerah dengan potensi kerang lumpur. Di kedua daerah terdapat potensi kerang lumpur $A$. edentula yang merupakan lokasi pengambilan kerang lumpur yang tergolong intensif.

Pemanfaatan tak terkendali oleh masyarakat lokal yang telah lama mengkonsumsi kerang lumpur, dikhawatirkan dapat mengakibatkan penurunan besar populasi dan tingkat keragaman, bahkan dapat berdampak terhadap kepunahan (Natan, 2008). Selanjutnya dikatakan bahwa, perubahan ekosistem sebagai akibat dari konversi hutan mangrove, pencemaran akibat sampah domestik, bencana alam, penggunaan racun maupun sebab-sebab lain, menyebabkan terjadinya kerusakan habitat organisme di perairan yang merupakan habitat dari berbagai organisme laut, termasuk Moluska. Kondisi seperti ini terjadi di perairan pesisir Pulau Tobea dan Pesisir Lambiku, Kecamatan Napabalano, Kabupaten Muna. Kerusakan habitat, khususnya pada daerah ekosistem mangrove, akan memberikan dampak yang cukup serius. Dampak dari kerusakan akan berpengaruh langsung terhadap kerang lumpur yang merupakan salah satu jenis Moluska dan berpotensi sebagai sumberdaya alam yang memiliki nilai gizi tinggi dan disukai oleh masyarakat lokal sebagai bahan makanan alami, dan memiliki peluang pasar yang ekonomis.

Kurang lebih $80 \%$ atau sekitar 8.000 dari spesies Bivalvia hidup di berbagai kedalaman pada semua lingkungan perairan laut dan sisanya di air tawar (Brusca dan Brusca, 2002). Selanjutnya dikatakan bahwa Bivalvia biasa juga disebut Pelecypoda (Yunani; pelecys $=$ kapak; podos $=$ kaki) atau juga dikenal sebagai Lamellibranchia (Poutiers, 1998). Kebanyakan dari kelas Bivalvia atau Pelecypoda membenamkan diri dalam lumpur, baik pada lingkungan perairan laut maupun tawar (Brusca dan Brusca, 2002).

Bivalvia (oysters, scallops, clams, cachles dan mussels) merupakan potensi sumberdaya penting di Indonesia, yang pada kenyataannya hampir semua spesies dari Bivalvia dapat dimanfaatkan untuk berbagai kebutuhan manusia meskipun hanya beberapa jenis bernilai ekonomis penting. Di Indo-Pasifik ditemukan kira-kira 17 famili Bivalvia yang terdapat di hutan mangrove, yaitu Archidae, Ostridae, Isognomonidae, Anomiidae, Mytilidae, Corbiculidae, Tellinidae, Solenidae, Cultellidae, Laternulidae, 
Lucinidae, Pholadidae, Teredinidae, Asophidae, Psammobidae, Blancomidae, dan Veredinidae. Bivalvia menyebar di daerah mangrove Avicenia, Rhizopora, Laguncularia, Conocarpus, dan lain-lain (Morton, 1983).

Di antara famili di atas, Anodontia edentula (Linneaus, 1758) merupakan anggota famili Lucinidae yang menyebar pada daerah mangrove dan dapat dikonsumsi serta bernilai ekonomis sebagai sumber protein (Carpenter dan Niem, 1998) (Gambar $1)$.

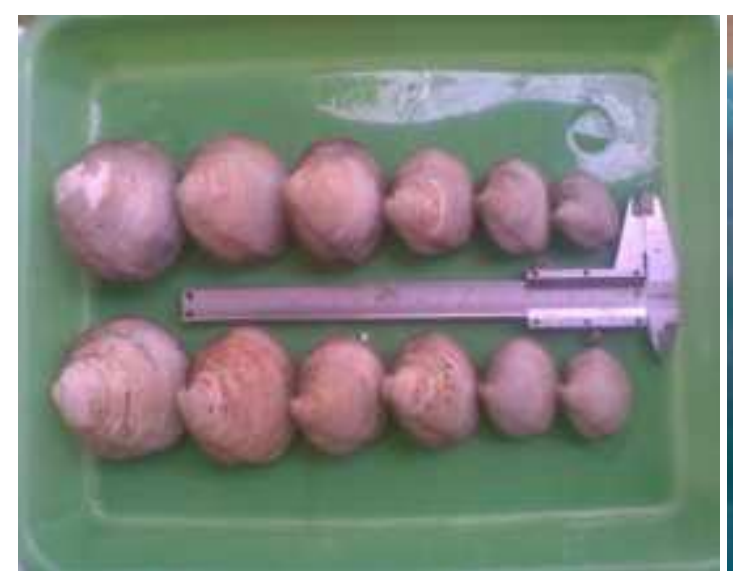

(A)

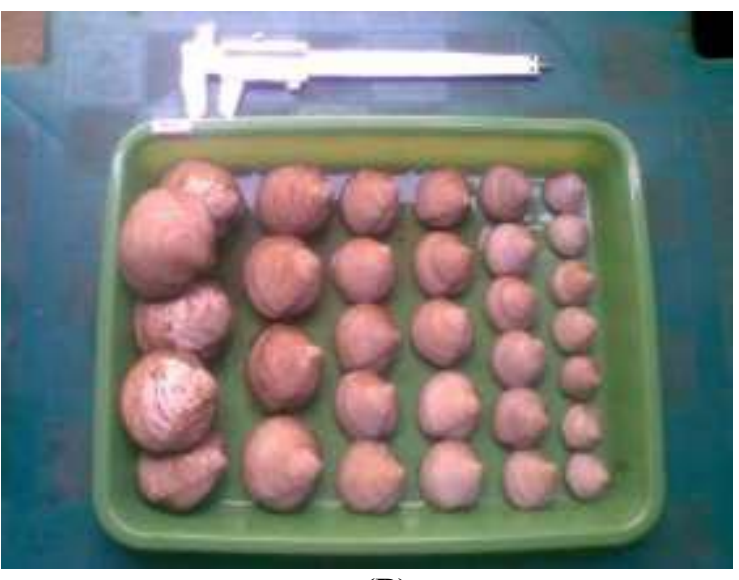

(B)

Gambar 1. Anodontia edentula Linnaeus, 1758 (A) di Pesisir Lambiku, (B) di Pulau Tobea, Kecamatan Napabalano, Kabupaten Muna (Sumber: foto penelitian, 2011).

A. edentula mendiami areal berlumpur dekat aliran sungai dan estuaria. Kebiasaan hidup $A$. edentula dengan membenamkan diri dalam lumpur (mudflat) pada kedalaman 28 - $50 \mathrm{~cm}$ secara berkelompok pada daerah mangrove di intertidal dan subtidal (Natan, 2008). A. edentula menyimpan bakteri pengoksidasi sulfur pada insangnya (Lebata, 2000). Sebagaimana halnya dikatakan Taylor dan Glover (2000, 2004 dan 2007) dan Cosel (2006), dapat digunakan sebagai biofilter (Lebata dan Primavera, 2001; Lebata, 2001). Selain itu, kerang lumpur juga dapat meningkatkan kadar estradiol dalam darah pada manusia yang mengkonsumsi kerang lumpur (Sjafaraenan, 2011).

Di Filipina dan Thailand, A. edentula dikenal dengan nama imbaw. Di Indonesia, kerang ini kurang dikenal dan baru pertama kali diperkenalkan dalam publikasi ilmiah oleh Natan dengan nama kerang lumpur (Natan, 2008). Di Kabupaten Muna, masyarakat lokal menyebutnya ghiwo yang ditemukan melimpah di perairan estuaria Pulau Tobea dan Pesisir Lambiku, Kecamatan Napabalano. A. edentula dimanfaatkan sebagai sumber protein hewani dengan kandungan gizi yang memiliki komposisi kadar air 80\%, protein 10,8\%, lemak 1,6\%, abu 0,75\% dan karbohidrat $0,6 \%$ (Natan, 2008). Kandungan gizi kerang lumpur di daerah Kabupaten Muna dengan komposisi protein 7,182\%, karbohidrat 66,887\%, lemak 6,820\%, kolesterol 10,00 $\mathrm{mg} / \mathrm{dl}$, HDL, 6,00 mg/dl, Ca 263,385 ppm, Cu 9,107 ppm, Mg 28,467 ppm, Fe 1,859 ppm, dan LDL serta Zn konsentrasi tidak terdeteksi (Sjafaraenan, 2011).

Di Indonesia, secara umum kerang lumpur $A$. edentula kurang mendapat perhatian. Di Kabupaten Muna, kerang ini tidak diidentifikasi sebagai salah satu komoditas perikanan oleh SKPD Kelautan dan Perikanan Kabupaten Muna. Selain itu, 
informasi tentang spesies ini masih sangat sedikit. Padahal spesies ini mempunyai nilai ekonomis, ekologis dan nilai gizi yang cukup tinggi, tetapi penelitian-penelitian tentangnya masih sangat kurang. Penelitian mengenai beberapa aspek biologi dan reproduksi spesies ini hanya dilaporkan oleh Natan (2008) dan eksplorasi sumberdaya di Teluk Ambon Bagian Dalam oleh Latale (2003). Untuk daerah pesisir Napabalano, Kabupaten Muna, penelitian dilakukan oleh Sjafaraenan (2011) tentang pengaruh konsumsi kerang lumpur terhadap kandungan hormon estradiol dalam darah.

Minimnya bahkan hampir tidak adanya data dan informasi tentang kerang lumpur ini sangat disayangkan, bila terjadi kepunahan sebelum informasi dasar mengenai aspek biologi terungkap. Sebagaimana yang dilaporkan Glover dan Taylor (2007) bahwa kelas Bivalvia, khususnya famili Lucinidae, memiliki keanekaragaman tinggi dengan persebaran secara geografik dari Indo-Pasifik Barat hingga perairan Atlantik Barat pada lingkungan oligotropik, akan tetapi data biologi dan ekologinya tidak tersedia.

Oleh karena itu, merupakan suatu hal yang penting untuk mengungkap informasi biologi khususnya mengenai karakter morfometrik kerang lumpur. Penelitian ini merupakan suatu upaya untuk mengungkapkan salah satu aspek biologi yakni karakter morfometrik kerang lumpur $A$. edentula yang berada di Pulau Tobea dan di Pesisir Lambiku, Kecamatan Napabalano, Kabupaten Muna. Informasi yang diperoleh diharapkan dapat memberikan nilai tambah terhadap informasi kekerangan di Indonesia.

\subsection{Tujuan}

Penelitian dilaksanakan dengan tujuan untuk menganalisis :

1. Karakter mofometrik kerang lumpur Anodontia edentula Linnaeus, 1758 di Pulau Tobea, Kabupaten Muna,

2. Karakter mofometrik kerang lumpur Anodontia edentula Linnaeus, 1758 di Pesisir Lambiku, Kabupaten Muna, dan

3. Perbedaan karakter morfometrik kerang lumpur Anodontia edentula Linnaeus, 1758 di dua daerah penelitian.

\subsection{Kegunaan}

Penelitian diharapkan dapat memberikan informasi mengenai :

1. Karakter mofometrik kerang lumpur Anodontia edentula Linnaeus, 1758 di Pulau Tobea, Kabupaten Muna,

2. Karakter mofometrik kerang lumpur Anodontia edentula Linnaeus, 1758 di Pesisir Lambiku, Kabupaten Muna, dan

3. Perbedaan karakter morfometrik kerang lumpur Anodontia edentula Linnaeus, 1758 di dua daerah penelitian.

\section{BAB 2. BAHAN DAN METODE}

\subsection{Tempat dan Waktu}

Penelitian dilakukan di Pulau Tobea dan Pesisir Lambiku, Kecamatan Napabalano, Kabupaten Muna (Gambar 2). Pengambilan contoh dilakukan pada bulan Maret sampai bulan Mei 2011 dengan interval waktu koleksi contoh dilakukan sebulan sekali selama tiga bulan. 


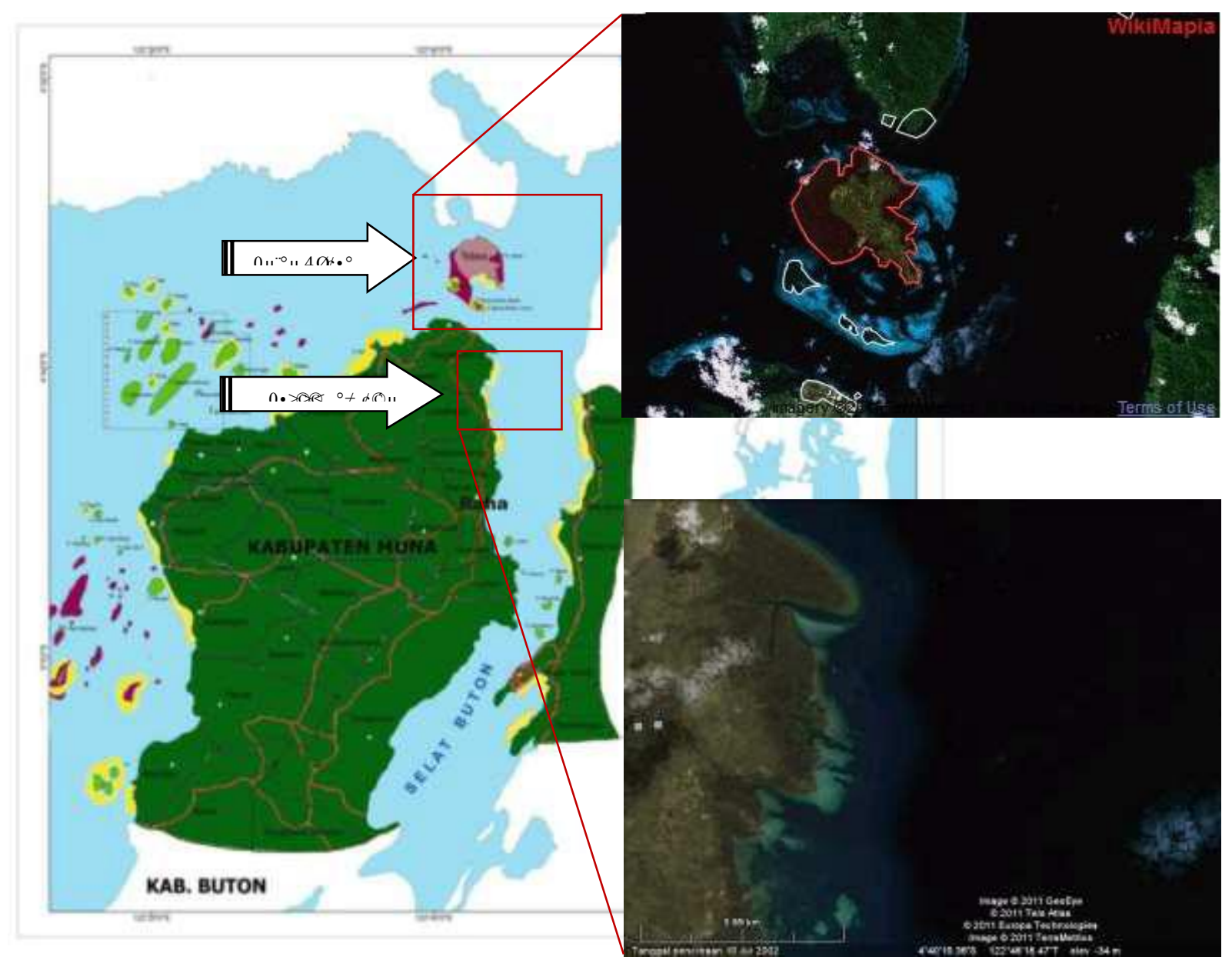

Gambar 2. Lokasi pengambilan contoh kerang lumpur Anodontia edentula Linnaeus, 1758 di Pulau Tobea dan Pesisir Lambiku, Kecamatan Napabalano, Kabupaten Muna (Sumber: D KP Muna, 2011).

\subsection{Alat dan Bahan}

Peralatan yang digunakan untuk mengukur tingkat kerapatan dan tutupan mangrove adalah roll meter dengan panjang $100 \mathrm{~m}$, patok plot dan tali rafiah serta alat tulis menulis. Untuk parameter biologi, peralatan yang digunakan adalah ember untuk menyimpan contoh kerang, timbangan elektrik dengan ketelitian 0,01 g untuk mengukur bobot tubuh (cangkang dan viscera). Kaliper dengan ketelitian 0,01 mm untuk mengukur morfologi. Dokumentasi penelitian dengan menggunakan camera dan alat tulis menulis.

\subsection{Prosedur Penelitian}

Koleksi contoh kerang lumpur dilakukan dengan menggunakan Metode Transek Garis (Line Transect Plot Method) yang ditentukan secara sengaja (purposive sampling) yang terdiri atas tiga plot pencuplikan. Pencuplikan kerang lumpur dilakukan untuk mewakili kategori daerah dekat pantai (Plot I), daerah peralihan (Plot II) dan daerah yang jauh dari pantai (Plot III), sepanjang transek garis yang dibuat dengan jarak interval $50 \mathrm{~m}$ pada masing-masing plot pencuplikan. 
Koleksi contoh dilakukan pada saat surut terendah dengan cara menggali substrat sampai kedalaman $30 \mathrm{~cm}$ atau menggali lumpur hingga menemukan individu kerang lumpur. Selanjutnya hasil koleksi kerang lumpur disimpan dalam wadah ember.

Pengukuran karakter morfometrik menggunakan kaliper dengan ketelitian 0,01 mm yang meliputi panjang, lebar dan tebal cangkang. Panjang cangkang adalah jarak dari ujung anterior ke ujung posterior cangkang. Lebar cangkang adalah jarak yang diukur pada bagian dorsal ke bagian ventral cangkang. Tebal cangkang adalah jarak yang diukur dari tepi cangkang pada bagian atas ke tepi cangkang pada bagian bawah (Gambar 3). Dokumentasi penelitian dengan menggunakan camera digital dan alat tulis menulis.

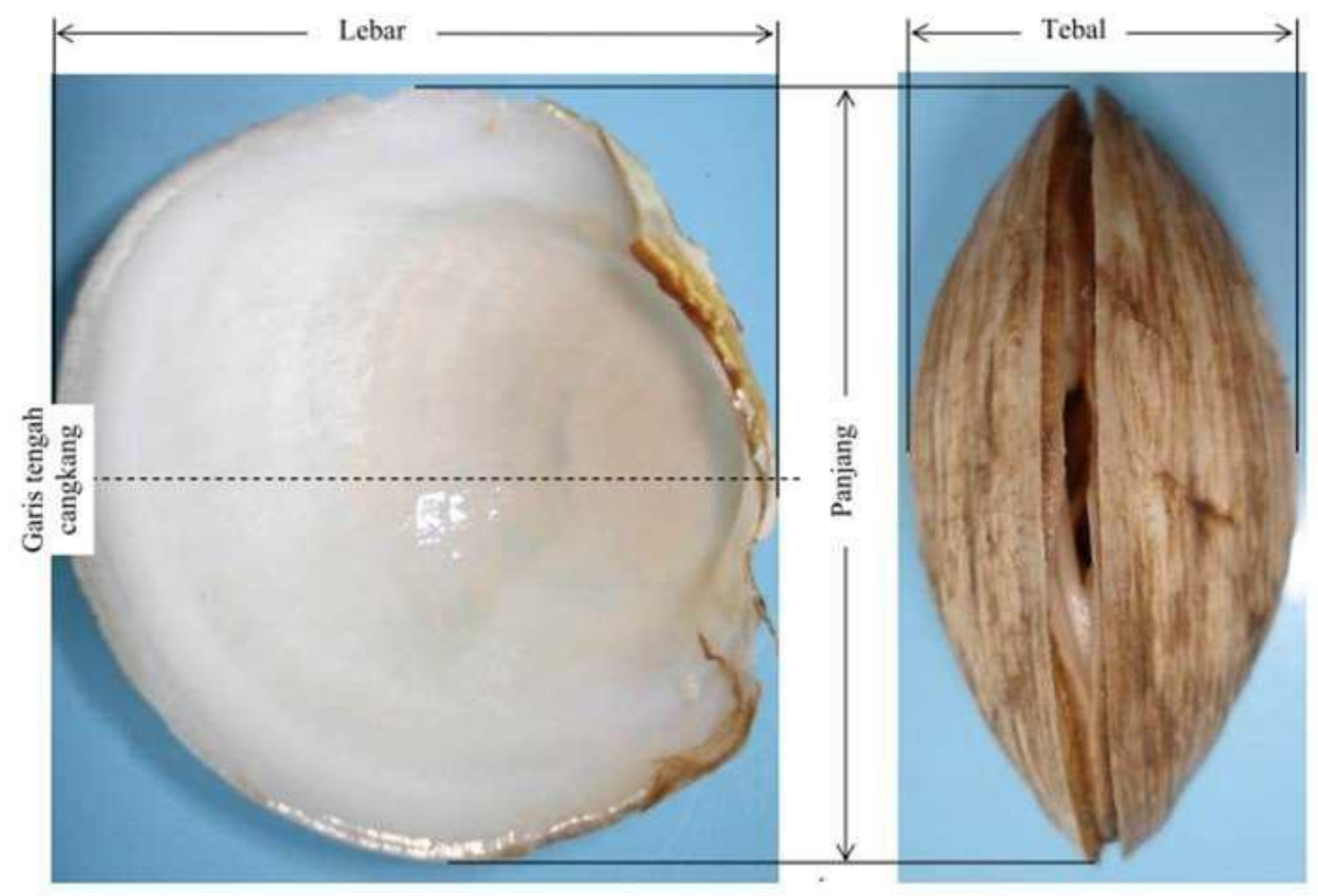

Gambar 3. Pengukuran karakter morfometrik kerang lumpur contoh, meliputi panjang (mm), lebar ( $\mathrm{mm})$ dan tebal cangkang $(\mathrm{mm})$ (Sumber: Yuliana, 2008)

\subsection{Analisis Data}

Data karakter morfometrik meliputi, panjang (P), lebar (L) dan tebal cangkang (T) disajikan dalam bentuk tabel statistik. Untuk mengetahui perbandingan karakter morfometrik kerang lumpur berdasarkan jenis kelamin antara Pulau Tobea dan Pesisir Lambiku, menggunakan uji-t (t-student) (Fowler dan Cohen, 1992), dengan formula sebagai berikut.

$$
t_{\text {hitung }}=\frac{\frac{\mathrm{S}}{\bar{\omega}}-\mu_{0}}{\overline{\bar{n}}}
$$

dimana $t_{\text {hitung }}=$ nilai yang dihitung dan menunjukkan nilai standar deviasi dari distribusi $\mathrm{t}($ Tabel $\mathrm{t}) . \mathrm{ih}=$ rata-rata yang diperoleh dari data. $\mu_{0}=$ nilai yang hipotesiskan. $\mathrm{S}=$ standar deviasi sampel yang dihitung. $\mathrm{N}=$ jumlah sampel penelitian. 


\section{BAB 3. HASIL DAN PEMBAHASAN}

Jumlah kerang lumpur yang berhasil dikoleksi selama penelitian di Pulau Tobea sebanyak 918 individu yang terdiri atas 415 jenis kelamin jantan dan 503 jenis kelamin betina. Di Pesisir Lambiku berhasil dikoleksi sebanyak 272 individu kerang lumpur yang terdiri atas 131 jenis kelamin jantan dan 141 jenis kelamin betina.

Morfometrik organisme khususnya kerang lumpur dan berbagai organisme perairan lainnya diperlukan untuk menggambarkan karakter penciri dari morfologi organisme itu sendiri.

Hasil analisa uji-t (student), perbandingan karakter morfometrik kerang lumpur pada daerah Pulau Tobea dan Pesisir Lambiku antara jenis kelamin jantan dan betina, dapat dilihat pada Tabel 1 sampai 4 berikut.

Tabel 1. Perbandingan karakter morfometrik antara kerang lumpur Anodontia edentula, Linnaeus 1758 jantan di Pulau Tobea $(n=415)$ dan jantan di Pesisir Lambiku (n=131) Kecamatan Napabalano, Kabupaten Muna

\begin{tabular}{|c|c|c|c|c|c|c|c|c|c|}
\hline \multirow{2}{*}{ Variabel } & \multicolumn{3}{|c|}{ Pulau Tobea } & \multicolumn{3}{|c|}{ Pesisir Lambiku } & \multicolumn{2}{|c|}{ Nilai t } & \multirow{2}{*}{ Keterangan } \\
\hline & Rerata & Deviasi & Varians & Rerata & Deviasi & Varians & hitung & $(\alpha=\mathbf{0 , 0 5})$ & \\
\hline Panjang cangkang (mm) & 43,23 & 7,27 & 52,85 & 51,89 & 6,88 & 47,30 & 12,3926 & 1,9704 & Berbeda nyata \\
\hline Lebar cangkang (mm) & 41,13 & 7,51 & 56,34 & 49,15 & 6,91 & 47,70 & 11,3327 & 1,9701 & Berbeda nyata \\
\hline Tebal cangkang $(\mathrm{mm})$ & 23,93 & 5,53 & 30,56 & 29,05 & 5,00 & 24,98 & 9,9445 & 1,9699 & Berbed a nyata \\
\hline
\end{tabular}

Sumber : data diolah dari hasil penelitian, 2011

Tabel 2. Perbandingan karakter morfometrik antara kerang lumpur Anodontia edentula, Linnaeus 1758 jantan di Pulau Tobea $(n=415)$ dan betina di Pesisir Lambiku $(n=141)$ Kecamatan Napabalano, Kabupaten Muna

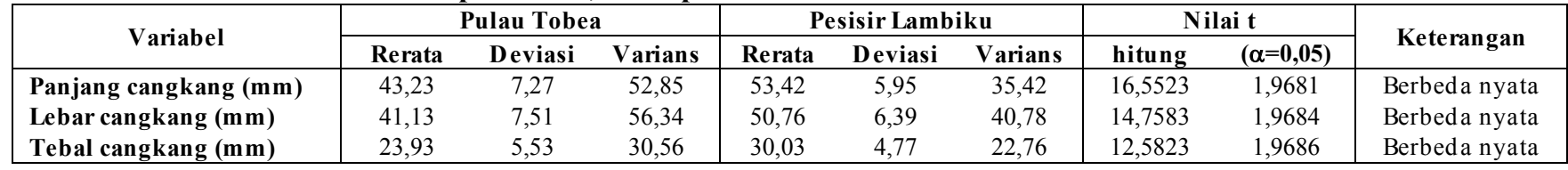

Sumber : data diolah dari hasil penelitian, 2011

Tabel 3. Perbandingan karakter morfometrik antara kerang lumpur Anodontia edentula, Linnaeus 1758 betina di Pulau Tobea $(n=503)$ dan jantan di Pesisir Lambiku (n=131) Kecamatan Napabalano, Kabupaten Muna

\begin{tabular}{|c|c|c|c|c|c|c|c|c|c|}
\hline \multirow{2}{*}{ Variabel } & \multicolumn{3}{|c|}{ Pulau Tobea } & \multicolumn{3}{|c|}{ Pesisir Lambiku } & \multicolumn{2}{|c|}{ Nilai t } & \multirow{2}{*}{ Keterangan } \\
\hline & Rerata & Deviasi & Varians & Rerata & Deviasi & Varians & hitung & $(\alpha=\mathbf{0 , 0 5})$ & \\
\hline Panjang cangkang (mm) & 45,25 & 6,68 & 44,67 & 51,89 & 6,88 & 47,30 & 9,9011 & 1,9720 & Berbeda nyata \\
\hline Lebar cangkang (mm) & 42,95 & 7,31 & 53,37 & 49,15 & 6,91 & 47,70 & 9,0410 & 1,9712 & Berbeda nyata \\
\hline Tebal cangkang (mm) & 25,25 & 5,31 & 28,20 & 29,05 & 5,00 & 24,98 & 7,6447 & 1,9712 & Berbeda nyata \\
\hline
\end{tabular}

Sumber : data diolah dari hasil penelitian, 2011

Tabel 4. Perbandingan karakter morfometrik antara kerang lumpur Anodontia edentula, Linnaeus 1758 betina di Pulau Tobea $(n=503)$ dan betina di Pesisir Lambiku (n=141) Kecamatan Napabalano, Kabupaten Muna

\begin{tabular}{|c|c|c|c|c|c|c|c|c|c|}
\hline \multirow{2}{*}{ Variabel } & \multicolumn{3}{|c|}{ Pulau Tobea } & \multicolumn{3}{|c|}{ Pesisir Lambiku } & \multicolumn{2}{|c|}{ Nilai t } & \multirow{2}{*}{ Keterangan } \\
\hline & Rerata & Deviasi & Varians & Rerata & Deviasi & Varians & hitung & $(\alpha=\mathbf{0 , 0 5})$ & \\
\hline Panjang cangkang (mm) & 45,25 & 6,68 & 44,67 & 53,42 & 5,95 & 35,42 & 14,0013 & 1,9696 & Berbeda nyata \\
\hline Lebar cangkang (mm) & 42,95 & 7,31 & 53,37 & 50,76 & 6,39 & 40,78 & 12,4187 & 1,9694 & Berbeda nyata \\
\hline Tebal cangkang ( $\mathrm{mm})$ & 25,25 & 5,31 & 28,20 & 30,03 & 4,77 & 22,76 & 10,2605 & 1,9697 & Berbeda nyata \\
\hline
\end{tabular}

Sumber : data diolah dari hasil penelitian, 2011

Berdasarkan Tabel 1 sampai 4, memperlihatkan bahwa karakter morfometrik (panjang, lebar dan tebal cangkang) di kedua daerah, berbeda nyata baik berdasarkan 
jenis kelamin yang sama maupun pada jenis kelamin yang berbeda. Hal ini ditunjukkan dengan nilai t hitung lebih besar dari t tabel pada taraf kepercayaan 0,05. Berdasarkan hal tersebut, menginformasikan bahwa perbedaan lokasi menunjukkan karakter morfometrik yang berbeda, baik pada jenis kelamin yang sama, maupun pada jenis kelamin yang berbeda.

Perbedaan karakter morfometrik panjang, lebar dan tebal cangkang kerang lumpur berdasarkan lokasi yakni Pulau Tobea dan Pesisir Lambiku maupun berdasarkan jenis kelamin jantan dan betina menunjukkan variasi karakteristik morfometrik yang berbeda pada setiap lokasi maupun berdasarkan jenis kelamin.

Perubahan karakter morfometrik kerang lumpur baik berdasarkan lokasi maupun berdasarkan jenis kelamin menunjukkan adanya perbedaan faktor lingkungan. Pada lokasi Pulau Tobea, kerang lumpur dengan karakter morfometrik yang cenderung lebih kecil dibandingkan dengan kerang lumpur di Pesisir Lambiku. Perbedaan ditunjukkan dengan keadaan mangrove dan perbedaan lokasi itu sendiri, yakni Pulau Tobea yang jauh dari aktifitas manusia dan lebih banyak mendapatkan pengaruh dari laut, sementara daerah Pesisir Lambiku dengan keadaan mangrove yang tergolong tebal dan lebih banyak mendapat pengaruh dari darat dengan aliran sungai besar yang diduga membawa aliran nutrien yang cukup untuk pertumbuhan yang baik bagi kerang lumpur (Rochmady, 2011).

Perbedaan karakter morfometrik antara jenis kelamin jantan dan betina baik pada lokasi yang sama maupun pada lokasi yang berbeda, menunjukkan bahwa kerang lumpur jenis kelamin betina memiliki kecepatan pertumbuhan yang lebih tinggi dibanding kerang lumpur jenis kelamin jantan (Rochmady, 2011).

Selain karena adanya perbedaan faktor lingkungan yang mendukung pertumbuhan, juga karena adanya pengaruh genetik dari spesies itu sendiri. Hal ini sejalan dengan pendapat Effendie (1997) yang menyatakan bahwa perbedaan lokasi dan jenis kelamin berdampak terhadap perbedaan variasi ukuran morfometrik suatu individu yang sama. Hal yang sama diperoleh Natan (2008) terhadap spesies yang sama menunjukkan bahwa, terdapat variasi ukuran morfometrik pada setiap stasiun pengamatan.

\section{BAB 5. KESIMPULAN DAN SARAN}

\subsection{Kesimpulan}

Berdasarkan pembahasan, dapat disimpulkan beberapa hal sebagai berikut.

1. Di daerah Pulau Tobea, karakter morfometrik kerang lumpur jenis kelamin jantan memiliki rata-rata ukuran panjang, lebar dan tebal cangkang berturut-turut sebesar $43,23 \mathrm{~mm}, 41,13 \mathrm{~mm}$ dan $23,93 \mathrm{~mm}$, untuk jenis kelamin betina berturut-turut sebesar 45,25 mm, 42,95 mm dan 25,25 mm.

2. Di daerah Pesisir Lambiku karakter morfometrik kerang lumpur jenis kelamin jantan memiliki rata-rata ukuran panjang, lebar dan tebal cangkang berturut-turut sebesar $51,89 \mathrm{~mm}, 49,15 \mathrm{~mm}$ dan $29,05 \mathrm{~mm}$, untuk jenis kelamin betina berturut-turut sebesar 53,42 mm, 50,76 mm dan 30,03 mm.

3. Morfometrik kerang lumpur berbeda, baik berdasarkan lokasi maupun berdasarkan jenis kelamin. 


\subsection{S a r a n}

Berdasarkan kesimpulan di atas, maka disarankan untuk ;

1. Perlu dilakukan penelitian lebih lanjut mengenai hubungan antara parameter lingkungan dengan parameter biologi.

2. Perlu dilakukan tindakan pengelolaan terhadap kerang lumpur, terutama di daerah Pesisir Lambiku.

\section{DAFTAR PUSTAKA}

Brusca, R.C. and GJ. Brusca. 2002. Invertebrata. Saunderland, Sinauer Associated. Inc Publishers. New york. 645-769p.

Carpenter, K.E. and V.H. Niem. 1998. Species Identification Guide for Fishery Purpose. The Living Marine Resources of The Western Central Pacific Volume I, Seaweeds, Corals, Bivalves, and Gastropods. Food and Agriculture Organization of The United Nations. Rome. Halaman 250.

Cosel, R.V. 2006. Taxonomy of tropical West African bivalves. VI. Remarks on Lucinidae (Mollusca, Bivalvia), with description of six new genera and eight new species. Zoosystema 28 (4) : 805-851.

Effendie, M.I. 1997. Biologi Perikanan. Yayasan Pustaka Utama. Yogyakarta. 163p.

Fowler, J. and L. Cohen. 1992. Practical Statistics for Field Biology. John Wiley and Sons. Chichester. Singapore.

Latale, S.S. 2003. Studi Pendahuluan Ekplorasi Sumberdaya Anodontia edentula Pada Perairan Pantai Desa Passo Teluk Ambon Bagian Dalam. Skripsi. Fakultas Perikanan Universitas Pattimura. Ambon. 58 hal.

Lebata, M.J.H.L. 2000. Elemental sulfur in the gills of the mangrove mud clam Anodontia edentula (Family Lucinidae). Journal of Shellfish Research 19(1): 241-245.

Lebata, M.J.H.L. 2001. Oxygen, sulphide and nutrient uptake of the mangrove mud clam Anodontia edentula (Family : Lucinidae). Marine Pollution Bulletin 11(42): 1133-1138.

Lebata, M.J.H.L. and J.H. Primavera. 2001. Gill structure, anatomy and habitat of Anodontia edentula; evidence of endosybiosis. Journal of Shellfish Research, 20(3): $1273-1278$.

Morton, B. 1983. The Molusca. Volume 6; Ecology Mangrove Bivalvia. Academic Press, Inc. Orlando, New York. pp $77-130$.

Natan, Y. 2008. Studi Ekologi dan Reproduksi Populasi Kerang Lumpur Anodontia edentula Pada Ekosistem Mangrove Teluk Ambon Bagian Dalam. Disertasi. Program Studi Ilmu dan Teknologi Kelautan. Institut Pertanian Bogor. Bogor. 179 hal.

Poutiers, J.M. 1998. Bivalves (Acephala, Lamellibranchia, Pelecypoda), pp 123-362. In Carpenter, K.E and V.H. Niem. 1998. FAO Species Identification Guide for 
Fishery Purposes. The Living Marine Resources of The Western Central Pacific 1. Seaweeds, Corals, Bivalves and Gastropods. Rome. 686p.

Rochmady. 2011. Aspek Bioekologi Kerang Lumpur Anodontia edentula Linnaeus, 1758 di Perairan Pesisir Kabupaten Muna. Tesis. Program Studi Ilmu Perikanan, Program Pascasarjana, Universitas Hasanuddin. Makassar.

Sjafaraenan. 2011. Pengaruh Konsumsi Daging Kerang Semele sp. Terhadap Kadar Estradiol Pada Wanita Perimenopause. Disertasi. Program Pascasarjana, Universitas Hasanuddin. Makasaar.

Taylor, J.D. and E.A. Glover. 2000. Functional anatomy, chemosymbiosis and evolution of the Lucinidae. Geological Society, London, Special Publications; 2000; $\quad$ v. $\quad 177 ; \quad$ p. http://sp.lyellcollection.org/cgi/content/abstract/177/1/207].

Taylor, J.D. and E.A. Glover., 2004. Systematic revision of Australian and IndoPacific Lucinidae (Mollusca: Bivalvia): Pillucina, Wallucina and descriptions of two new genera and four new species. Records of the Australian Museum 53(3): 263-292.

Taylor, J.D. dan E.A. Glover., 2007. Diversity of chemosymbiotic bivalves on coral reefs: Lucinidae (Mollusca, Bivalvia) of New Caledonia and Lifou. Zoosystema 29 (1) : 109-181. 